\title{
Melting and freezing beneath ice shelves: implications from a three-dimensional ocean-circulation model
}

\author{
J. Determann and R. Gerdes \\ Alfred-Wegener-Institut für Polar- und Meeresforschung, D-27515 Bremerhaven, Germany
}

\begin{abstract}
The thermohaline circulation below a regularly shaped ice shelf comparable in dimensions to the Ronne Ice Shclf, Antarctica, is investigated by means of a three-dimensional primitive-equation model. To handle the strongly inclined ocean surface as well as the bottom topography, we use scaled coordinates in the vertical direction. Preliminary results of two model versions containing open and closed open-ocean boundaries, respectively, prove the internal circulation is almost independent of the hydrography outside the ice shelf:

Mercly driven by the pressure-dependence of the sea-water freczing point $\left(-0.000753 \mathrm{~K} \mathrm{dbar}^{-1}\right.$, a stationary circulation pattern evolves, forced by the buoyancy flux due to melting and freezing. The redistribution of ice from deep to shallow ice-shelf drafts resembles the ice-pump mechanism. Its strength depends on the ice-thickness gradients, namely, the differences of the freezing point at the ice-shelf base. As simulated mclting and accumulation rates convincingly reproduce the interactions obscrved at the base of the Ronne Ice Shelf, the present model can act as a tool coupling ice-occan dynamics.
\end{abstract}

\section{INTRODUCTION}

Antarctica's ice shelves account for more than $40 \%$ of the continent's shorcline. By covering an area of $1.5 \times$ $10^{6} \mathrm{~km}^{2}$ (Drewry, 1983), they provide a large interface with the surrounding ocean. Mercer (1978) raised concern about the stability of the West Antarctic ice sheet (WAIS). Increased melting due to warmer inflowing water may cause the large ice shelves to disintegrate, reducing the back-pressure necessary to preserve the present ice-sheet profile. On the other hand, basal molting provides a strong, local heat sink to the Southern Ocean. Cold, dense ice-shelf water (ISW) flowing out from beneath the ice shelves is held as a source to the formation of Antarctic Bottom Water (AABW), which spreads far into the Northern Hemisphere to cool the global abyssal ocean (Fahrbach, 1993).

Several investigations to calculate the mass balance of the Antarctic ice sheet take into account the melting at the underside of ice shelves that may amount to as much as $544 \mathrm{~km}^{3}$ year ${ }^{-1}$ of water equivalent (Jacobs and others, 1992). Basal melting rates observed in many places by direct and indirect methods, locally exceed 9 myear $^{1}$ Berendt, 1970; Kohnen, 1982; Determann and others, 1990; Jenkins and Doake, 1991). Basal freezing was inferred from drillholes through the Amery, Ross and Filchner-Ronne Ice Shclves (Morgan, 1972; Zotikov and others, 1980; Engelhardt and Determann, 1987; Oerter and others, 1992). As found from ice-shelf modelling, basal accumulation reaches more than $2 \mathrm{~m} \mathrm{year}^{-1}$ in some parts of the Ronne Ice Shelf (Determann, 1991) and causes the formation of a basal layer of marine shelf icc. As found from airborne geophysical soundings, the basal ice reaches thicknesses of more than $300 \mathrm{~m}$ and locally accounts for more than $75 \%$ of the total ice column (Thyssen, 1988).

The process of melting at deep ice-shelf drafts close to the grounding line and a subsequent release of ice crystals from the raised and supercooled water masses in shallower areas has already been discussed by Doake (1976) and Robin (1979). Due to a gain of salt and latent heat from the formation of ice crystals, the water becomes denser and warmer, and tends to recirculate along an inlandsloping sea floor towards the grounding line to support further melting, thus closing a process named "ice pumping" (Lewis and Perkin, 1986).

Becausc oceanographic soundings are very difficult to undertake through ice shelves, several models have been used to investigate the oceanic circulation and possible causes of molting and freczing (MacAyeal, 1984, 1985; Hellmer and Olbers, 1989, 1991; Scheduikat and Olbers, 1990; Jenkins, 1991; Jenkins and Doake, 1991). Generally, these models support the common view that warm High Salinity Shelf Water (HSSW) ventilates the sub-ice cavity, providing the heat necessary for extensive melting at the ice-shelf base. HSSW transforms into ISW due to iceocean interaction. Potential temperatures below $-1.9^{\circ} \mathrm{C}$ (the approximate freezing point of sea water at the surface pressure (Millero, 1978)) characterized ISW that is found offshore from the main icc shelves of Antarctica.

The above-mentioned one- or two-dimensional models rely on parameterizations of physically important quantities, namely the zonal pressure gradient that governs the meridional transport. In a new attempt to model the thcrmohaline circulation beneath ice shelves, we introduce a three-dimensional primitive-equation model for ocean 
circulation. Initially developed by Bryan (1969), it has since been used for numerous applications of ocean modelling. Preliminarily, we apply the model to an idealized ice-shelf-ocean system having solely meridional gradients in ice thickness and water depth. Different cases of ice thickness and water-depth variations are investigated for a domain similar in extent to the Ronne Ice Shelf. We consider closed- as well as open-boundary conditions towards the open ocean to investigate the degree of selfsustenance of an ice-pump-driven internal circulation.

\section{MODEL BACKGROUND}

The model used in this study is a multi-level numerical model based on the Geophysical Fluid Dynamics Laboratory's general circulation model (Bryan, 1969; Cox, 1984). Here, we use a version with $\sigma$ coordinates $(\sigma=z / H)$ in the vertical (Gerdes, 1993). With this coordinate transformation, the inclined ocean surface and the sloping bottom both become coordinate surfaces providing for a convenient implementation of boundary conditions. The model predicts the horizontal-velocity components, potential temperature, salinity and additional passive tracers (e.g. $\delta^{18} \mathrm{O}$ ). The vertical velocity is diagnosed from the continuity equation for an incompressible fluid. Density is calculated from potential temperature, salinity and pressure, employing a polynomial fit (Mellor, 1991) to the equation of state defined by UNESCO (1981). A convective-adjustment procedure removes statically unstable density stratification that may arise during the calculation.

We investigate a regularly shaped model domain having only meridional gradients of ice thickness and water depth. Figure la displays ice-thickness distribution and water depths on meridional cross-sections through the model domain. The domain has $50 \times 50$ grid points with meridional and zonal resolution of $0.1^{\circ}$ and $0.3^{\circ}$, respectively. There are ten $\sigma$ levels in the vertical with

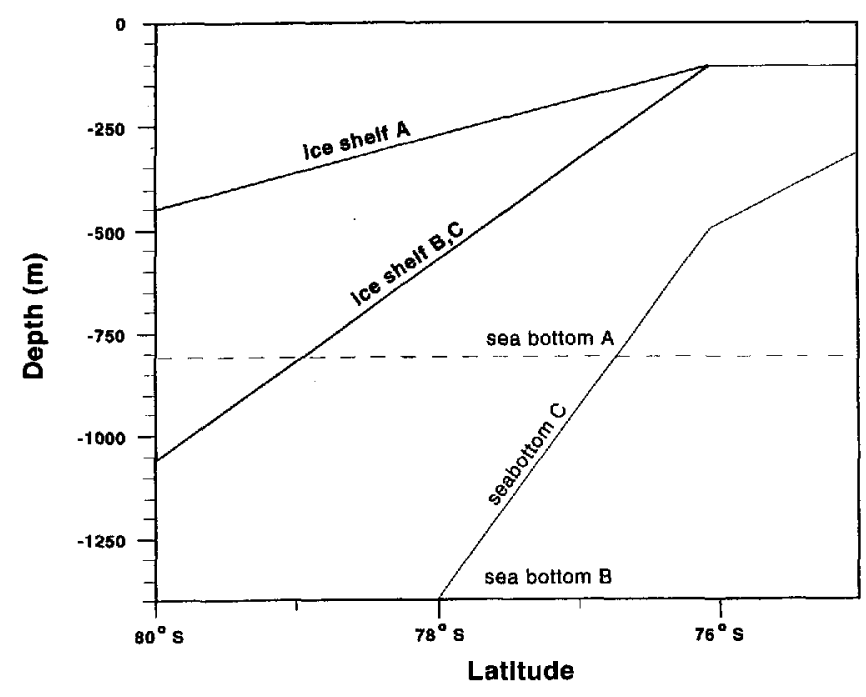

highest resolution near the ice-shell base ( $\Delta \sigma$ increasing with depth from 0.025 to 0.25 ).

The model is initialized with homogeneous temperatures and salinities on $\sigma$ levels. The temperature with depth-dependence is taken according to a profile mcasured by Nicholls and others (1991) below the central Ronne Ice Shelf. The profile shows a two-layer stratification consisting of a warmer bottom layer of about $-2^{\circ} \mathrm{C}$ and a colder one of about $-2.3^{\circ} \mathrm{C}$ near the ice-shelf base. The initial density profile is stable, because we choose a salinity increase from 34.40 psu (practical salinity units) at the ice-shelf base to $34.50 \mathrm{psu}$ at depth.

\section{BOUNDARY CONDITIONS}

The pressure-dependence of the freezing point of sea water (decreasing as $-7.53 \times 10^{-4} \mathrm{~km}^{-1}$ ) implies in-situ freezing points of $-2.6^{\circ} \mathrm{C}$ for an ice-shelf base at $1000 \mathrm{~m}$ depth. To prescribe the freezing point at depth $z$, we adopt a linear fit to the equation given by Millero (1978) according to

$$
T^{\text {ice }}=-1.89-7.53 \times 10^{-4} z .
$$

Due to the small range of salinity variations, their effect
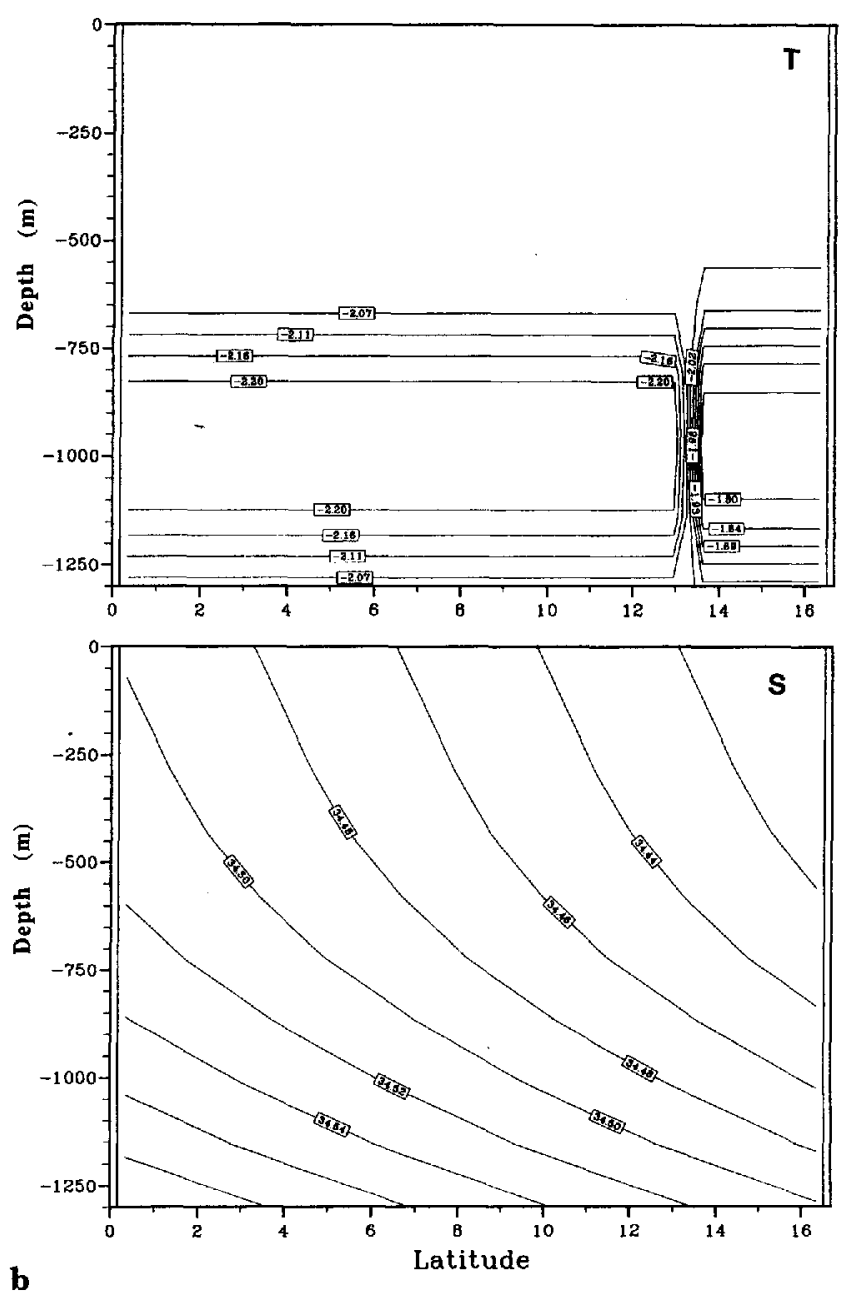

Fig. 1. a. Geometric set-up for the three-dimensional ice-shelf cavity. There are no zonal gradients in ice-shelf thickness and bottom lopography. Open-ocean boundary at $75^{\circ} \mathrm{S}$, grounding line al $80^{\circ} S .6 . T, S$ distribution serving as open-boundary values for inflow conditions (simplified after Foldvik and others, 1985). The vertical scale is compressed according to different waler depths in runs $A C$. Cold-and saline-water masses prevail in the west, while warm and less-saline waters occur at the model's eastern margin. 
on $T^{\text {ice }}$ is not taken into account. Anyway, the largest uncertainty in calculating heat fuxes across the ice-ocean boundary arises from adopting a constant coefficicnt for turbulent-heat exchange $\left(\gamma_{\mathrm{T}}=1 \times 10^{4} \mathrm{~ms}^{-1}\right.$; Hellmer and Olbers, 1989). Unlike Jenkins (1991), we assume $\gamma_{\mathrm{T}}$ is independent of velocity. The parameterization for heat flux

$$
Q^{\mathrm{T}}=\rho_{\mathrm{w}} c_{\mathrm{pw}} \gamma_{\mathrm{T}}\left(T^{\mathrm{ice}}-T^{\mathrm{w}}\right)
$$

results in a flux of $400 \mathrm{~W} \mathrm{~m}^{-2} \mathrm{~K}^{-1} . T^{\mathrm{w}}$ is the temperature in the uppermost ocean layer; its density, $\rho_{\mathrm{w}}$, is taken as $1028 \mathrm{~kg} \mathrm{~m}^{-3}$, and the specific-heat capacity at constant pressure $c_{\mathrm{pw}}=3950 \mathrm{~J} \mathrm{~kg}^{-1} \mathrm{~K}^{-1}$. Due to the variety of temperature gradients expected at the ice-shelf base, probably ranging from $0.30 \mathrm{~K} \mathrm{~m}^{-1}$ in a molting zone to less than $0.02 \mathrm{~K} \mathrm{~m}$ ' in an accumulation area, a sensibleheat flux is neglected. Besides, it would account for less than $0.1 \mathrm{~W} \mathrm{~m}^{-2}$ while latent-heat fluxes related to melting or ice-crystal formation may amount to more than $40 \mathrm{~W} \mathrm{~m}^{-2}$.

The heat flux through the ice-shelf-ocean boundary implies intensive fresh-water fluxes to the upper ocean box. In the casc of freezing, salinity increases due to extraction of fresh water from the ocean, while melting causes a reduction in salinity. Chemical analyses of marine shelf ice sampled on the Ronne Ice Shelf (Oerter and others, 1992), yielding salt concentrations far less than those found in sea ice, give a good reason to assume that salt is almost rejected from ice crystals accumulating at the base of the ice shelf. Thus, $Q^{\mathrm{T}}$ can casily bc transferred into fresh-water fluxes, according to

$$
m=Q^{\mathrm{T}} L \rho_{\text {ice }}
$$

where $L$ is the latent heat of fusion $\left(334 \mathrm{~kJ} \mathrm{~kg}^{-1}\right)$ and $\rho_{\text {ice }}$ is the density of ice $\left(920 \mathrm{~kg} \mathrm{~m}^{-3}\right)$. The thermohaline effects of heat and fresh-water fluxes at the ice-shclf base, cxpressed by Equations (2) and (3), provide the only forcing for the ocean model.
The velocity vanishes at horizontal boundaries (no slip) and there are no heat and fresh-water fluxes. The boundary with the open ocean at the ice-shelf front is taken differently in the model study. We investigate either (i) a closed boundary with only zonal flow and no meridional momentum flux (free slip) or (ii) an open boundary allowing the open ocean to exchange mass, tracer and momentum with the sub-ice-shelf cavity. In implementing the open-boundary condition, we follow Stevens (1991). In the case of outflow, tracer quantities are exported from the domain according to a radiationboundary condition. At inflow points, prescribed boundary values for $T$ and $S$ enter the domain. Instead of prescribing the vertically integrated mass transport $\Psi$ across the boundary, we chose the condition

$$
\frac{1}{a} \frac{\partial \Psi}{\partial \phi}=-\int_{-H-H_{\mathrm{ice}}}^{-H_{\mathrm{ice}}} u \mathrm{~d} z=0
$$

where $a$ is the Earth's radius, $\phi$ is the geographical latitude, $u$ is the zonal velocity component, $H$ is the thickness of the water column beneath the ice shelf and $H_{\text {ice }}$ is the depth of the ice-shelf base. Furthermore, we require the meridional frictional momentum flux to vanish at the boundary.

\section{EXPERIMENTS}

The experiments conducted for this study put special emphasis on geometric constraints for ocean circulation rather than investigating sensitivity with respect to physical parameters. Table 1 gives the configurations of three model runs $A, B$ and $C$, which were conducted for both open and closed boundaries with the open ocean. Variations of ice thickness $H_{\text {ice }}$ (more precisely, ice-shelf draft) are according to those found in real ice shelves, while bottom topography is kept flat in the ocean, except for run C. Actual water depths obscrved beneath the Ronne Ice Shelf posed for the bottom topography

Table 1. Overview on results of model runs $A, B$ and $C$. The depth difference $\Delta H_{\mathrm{ice}}$ at the ice-shelf base controls the rates

\begin{tabular}{|c|c|c|c|c|}
\hline $\operatorname{Run} / \Delta h_{\text {ice }}$ & Open-acean boundary & $\begin{array}{c}\text { Zonally integrated } \\
\text { stream function }\end{array}$ & $\begin{array}{l}\text { Vertically integrated } \\
\text { stream function }\end{array}$ & $\begin{array}{l}\text { Melting } \\
\text { freezing }\end{array}$ \\
\hline $\mathrm{m}$ & & $10^{6} \mathrm{~m}^{3} \mathrm{~s}^{1}$ & $10^{6} \mathrm{~m}^{3} \mathrm{~s}^{-1}$ & $\mathrm{ma}^{1}$ \\
\hline \multirow[t]{2}{*}{$\mathrm{A} / 380$} & Open & 0.054 & 0.28 & $-0.25-1.05$ \\
\hline & Close & 0.059 & 0.25 & $-0.22-1.09$ \\
\hline \multirow[t]{2}{*}{$\mathrm{B} / 970$} & Open & 0.310 & 1.35 & $-6.0-4.1$ \\
\hline & Close & 0.290 & 4.70 & $-6.3-4.3$ \\
\hline \multirow[t]{2}{*}{ C/970 } & Open & 0.095 & 2.65 & $-4.9-3.1$ \\
\hline & Close & 0.110 & 2.70 & $5.4-2.4$ \\
\hline
\end{tabular}
of melting (negative) and basal accumulation. The open ocean does not significanlly affect the pattern of ice ocean interaction. Intensified or weakened mean horizontal currents determine the spreading of melting and freezing zones 


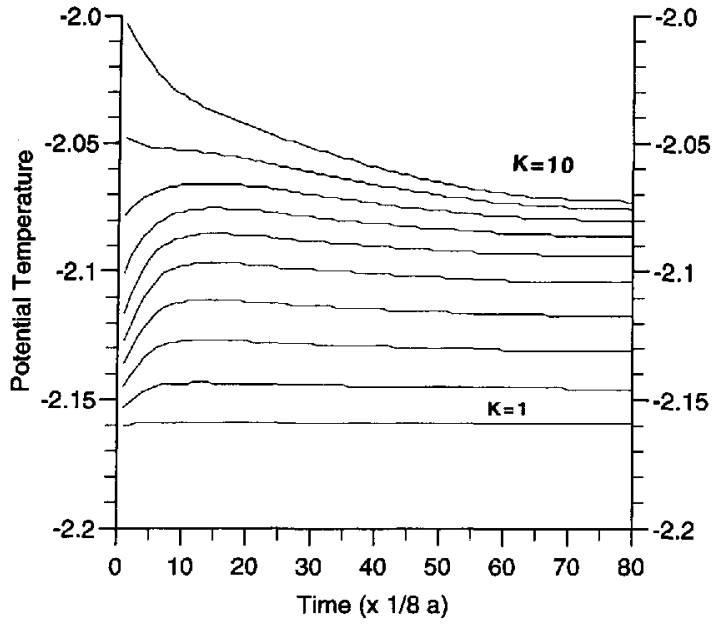

Fig. 2. Run $A$, spin-up time. The figure displays levelaveraged temperatures us integration time. While the uppermost layer $(k=1)$ adjusts very fast to the temperature at the ice-shelf base, thermohaline circulation needs decades to ventilate the deeper parts of the cavity.

adopted in run $\mathrm{C}$, rescmbling a common feature of inland-deepening slopes beneath Antarctic ice shelves.

Commonly, all model ice shelves have their strongest bottom slopes more inland, while small thickness gradients hold for the outermost ten grid points (Fig. la). This is to represent gentle slopes of the outer parts of real ice shelves arising from icc dynamics and decreasing effects of side shear in diverging embayments. When applying openboundary conditions, a CTD transect (conductivity, temperature, depth parallel to the ice front of the Filchner-Ronne Icc Shelf mcasurcd by Foldvik and others (1985) serves to prescribe $T, S$ profiles at the boundary. We simplified that part, off the Ronnc Ice Shelf, between the Antarctic Peninsula and Berkner Island to define a $T, S$ distribution according to Figure $1 \mathrm{~b}$.

All experiments start from an ocean at rest. 'l'o asscss the spin up of a modelled ocean circulation, we use the evolution of level mean temperatures during the integration to monitor the approach of stationarity (Fig. 2). Depending on the configuration, the model reaches a steady state after $20-50$ years of integration.

\section{RESULTS}

We first present the main circulation features for the subice-shelf cavity by means of vertically and zonally integrated mass-transport stream functions. Then, we investigate the interaction between circulation and thcrmohaline forcing. Finally, we compare results for open and closed northern boundaries.

The mean meridional circulation in the sub-ice-shelf cavity is represented by the stream function for the zonally integrated mass transport shown in Figure 3a for expcriment B. A northward transport near the ice-shelf base leads to strong sinking near the northern cdge of the domain. Up-welling of the southward return flow occurs somewhat uniformly south of $76^{\circ} \mathrm{S}$. The pattern resembles the results of Hellmer and Olbers (1991) and reflects the basic ice-pump mechanism. Compared to

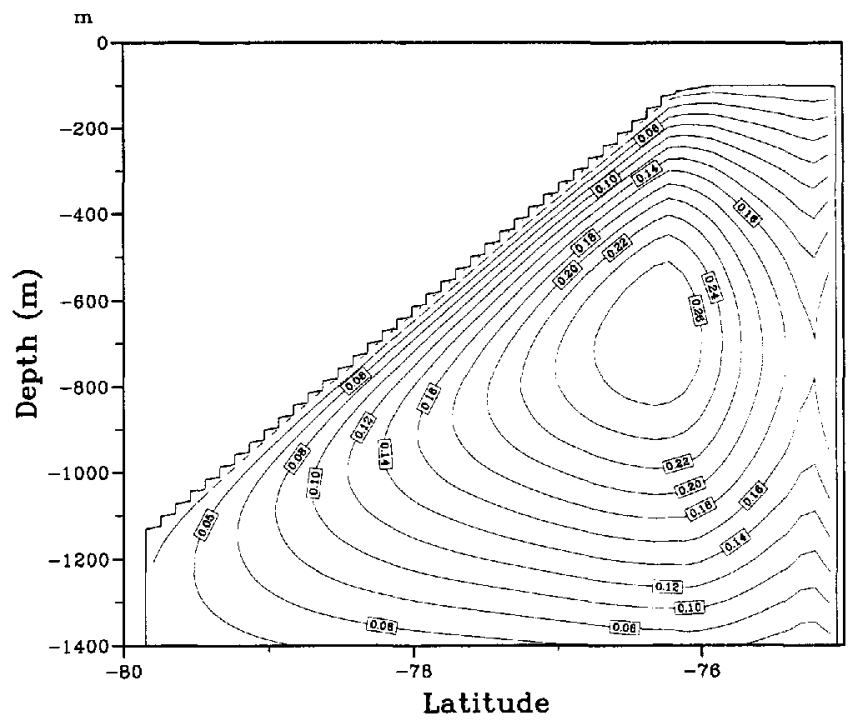

a

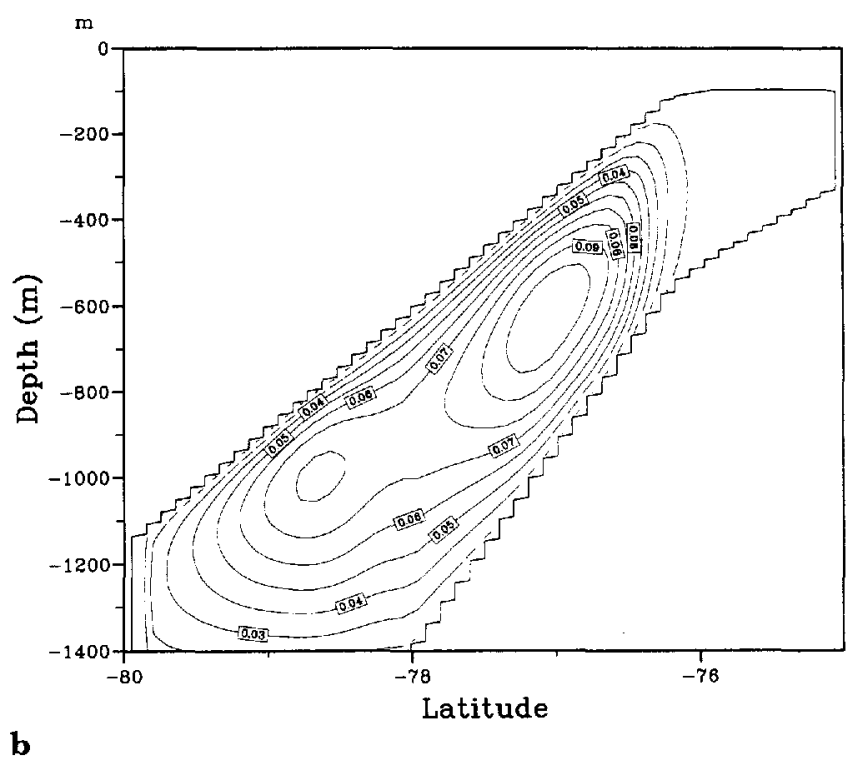

Fig. 3. Stream function of the zonally integrated mass iransport for experiments (a) $B$, and (b) $C$. Contour interval (a) $0.02 \mathrm{~Sv} \quad\left(1 \mathrm{~Sv}=10^{6} \mathrm{~m}^{3} \mathrm{~s}^{-1}\right)$, and $(b)$ 0.01 Si.

their results, the total transport of $0.3 \mathrm{~Sv} \quad(1 \mathrm{~Sv}=$ $10^{6} \mathrm{~m}^{3} \mathrm{~s}^{-1}$ ) is relatively small. The circulation cell, as in Figure $3 a$, also prevails in experiment A (not shown); however, with even smaller transports. With the more realistic topography of case $\mathrm{C}$, the circulation is somewhat modified (Fig. 3b) with down-welling south of $78^{\circ} \mathrm{S}$ as well as ncar the transition from an inclined to a flat iccshelf base further north. There is almost no meridional overturning north of $76^{\circ} \mathrm{S}$, which is a rather quiet region in this experiment.

While ascending along the ice-shelf base, the water becomes supercooled with respect to the local pressurefreezing point and releases ice crystals. The latent-heat release and the extraction of fresh water make the water warmer and denscr. Convective mixing removes unstable density stratification arising from ice formation, resulting in a thicker homogeneous layer beneath the ice shelf. 'The structure of the mixed layer can be inferred from the salinity section for case C (Fig. 4) along the western 


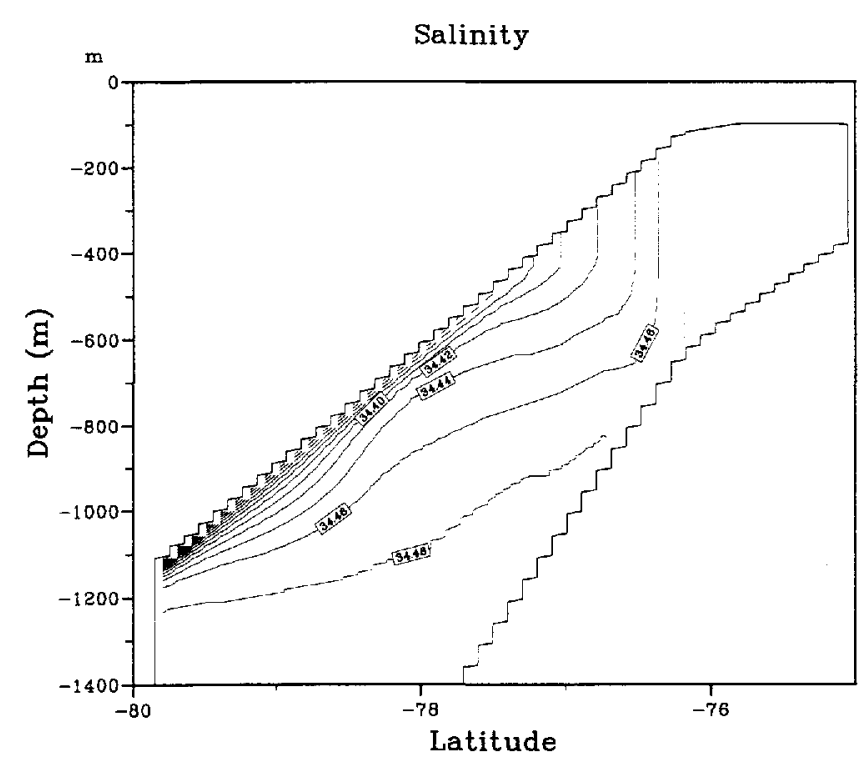

Fig. 4. Salinity section along the western boundary in experiment C. Conlour interval is $0.02 p s u$ (practical salinity units).

boundary. Eventually, the whole water column becomes well mixed in an area of extensive ice formation north of around $77^{\circ} \mathrm{S}$ in this case.

The stream function for the vertically integratcd transport indicates the prevailing horizontal circulation. The northward transport in case B (Fig. 5a) is confined to the westcrn boundary but it extends all the way through the basin. The southward return flow forms a tight recirculation near the northern edge, where the waterdepth gradient is small. The recirculation broadens where the ice draft increases towards the south. The slow southerly flow brings heat as a potential source of sustained melting to the grounding line. The more complicated water-column thickness gradient in case $\mathrm{C}$ results in a different transport pattern (Fig. 5b). A somewhat intense circulation of $2.7 \mathrm{~Sv}$ is centered around $78^{\circ} \mathrm{S}$, where the water-depth gradient changes sign (Fig. 1a). There is no indication of a western intensification of the circulation cell. Both, the rather large amplitudc and the lack of pronounced boundary currents can be explained by the reversal in sign of the background vorticity gradient, $\beta_{\text {tot }}=\beta-(f / a H) \partial H / \partial \phi$, with $\beta=$ $a^{-1} \partial f / \partial \phi$. The transports are proportional to the forcing divided by $\beta_{\text {tot }}$ in the large-scale limit. Small $\beta_{\text {tot }}$ makes the model very sensitive to changes in the forcing. $A$ s on an $f$ plane, there is no asymmetry between eastern and western boundaries.

The buoyancy fluxes associated with melting and freezing are the only forcings for the oceanic flow in our model. The fluxes shown in Figure $6 \mathrm{~b}$ for cases B and C are intimately coupled with the circulation itself. Generally, mclting is highest where warm watcr mocts the ice-shelf base first. This happens in the southeastern corner of the model domain. While the diluted water moves west at constant depth, melting rates become smaller until the heat potential is exhausted. Water temperatures next to the ice-shelf base now have approached $T_{\text {ice. }}$. During the subsequent rise with the northward current along the western boundary, the water bccomes increasingly supercooled and able to release ice

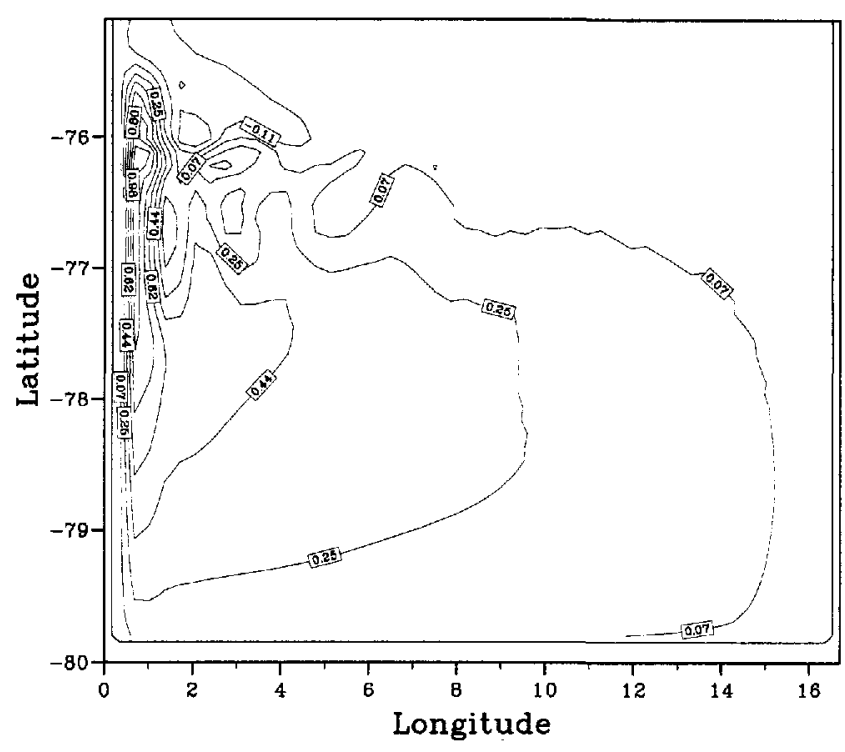

$\mathbf{a}$

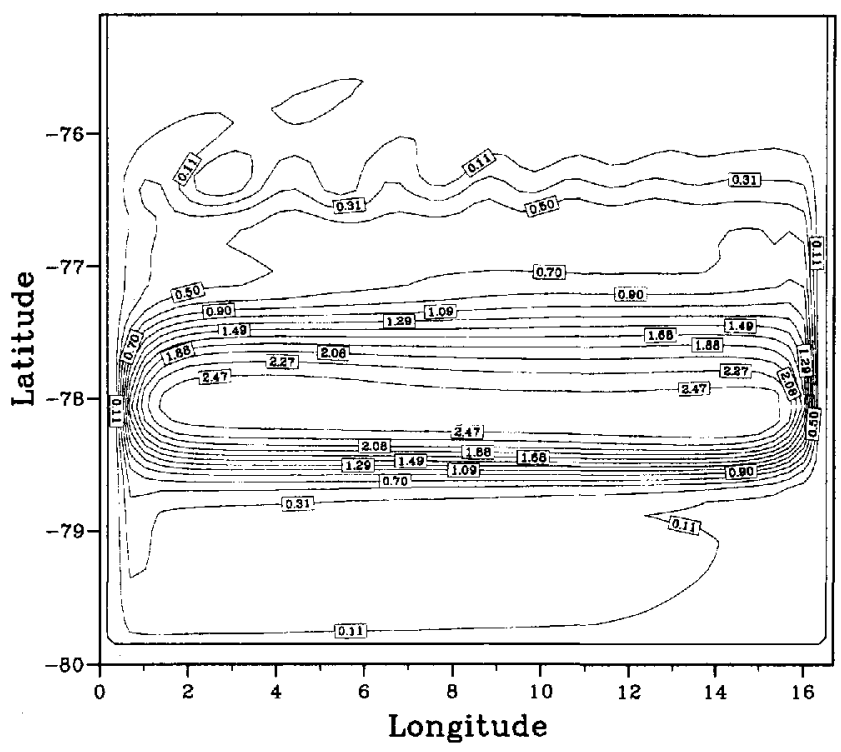

b

Fig. 5. Stream function of the vertically integrated mass transport $\Psi$. (a) Run $B$ : contour interval $0.18 \mathrm{~Sv}$; (b) run $C$ : contour interval $0.20 \mathrm{Su}$.

crystals most efficiently close to the onset of the flat part of the ice shelf. Table 1 displays the extreme values of melting and freezing for all cxperiments. It is obvious that $\Delta H_{\text {ice }}$ determines the potential for melting and freezing, and thus the magnitudes of mass exchange through the ice-shelf-ocean boundary. Comparing the two results in Figure 6 , it seems that the mean circulation guides the distribution of melting and freezing areas. When a balance between horizontal advection of heat and surface heat flux is assumed for the uppermost level, the surfacc fresh-water flux is proportional to the velocity and the horizontal temperature gradient. Largest fluxes occur where the velocities are large and/or the temperature changes rapidly, the latter imposed by the meridional changes in ice draft. In case $\mathrm{C}$, the strong currents near both the eastern and western boundaries, and their interior extensions, are locations of large fresh-water fluxes. Also, the transition from a steeply inclined to a flat ice-shelf base at $76^{\circ} \mathrm{S}$ stands out as an area of freezing. 

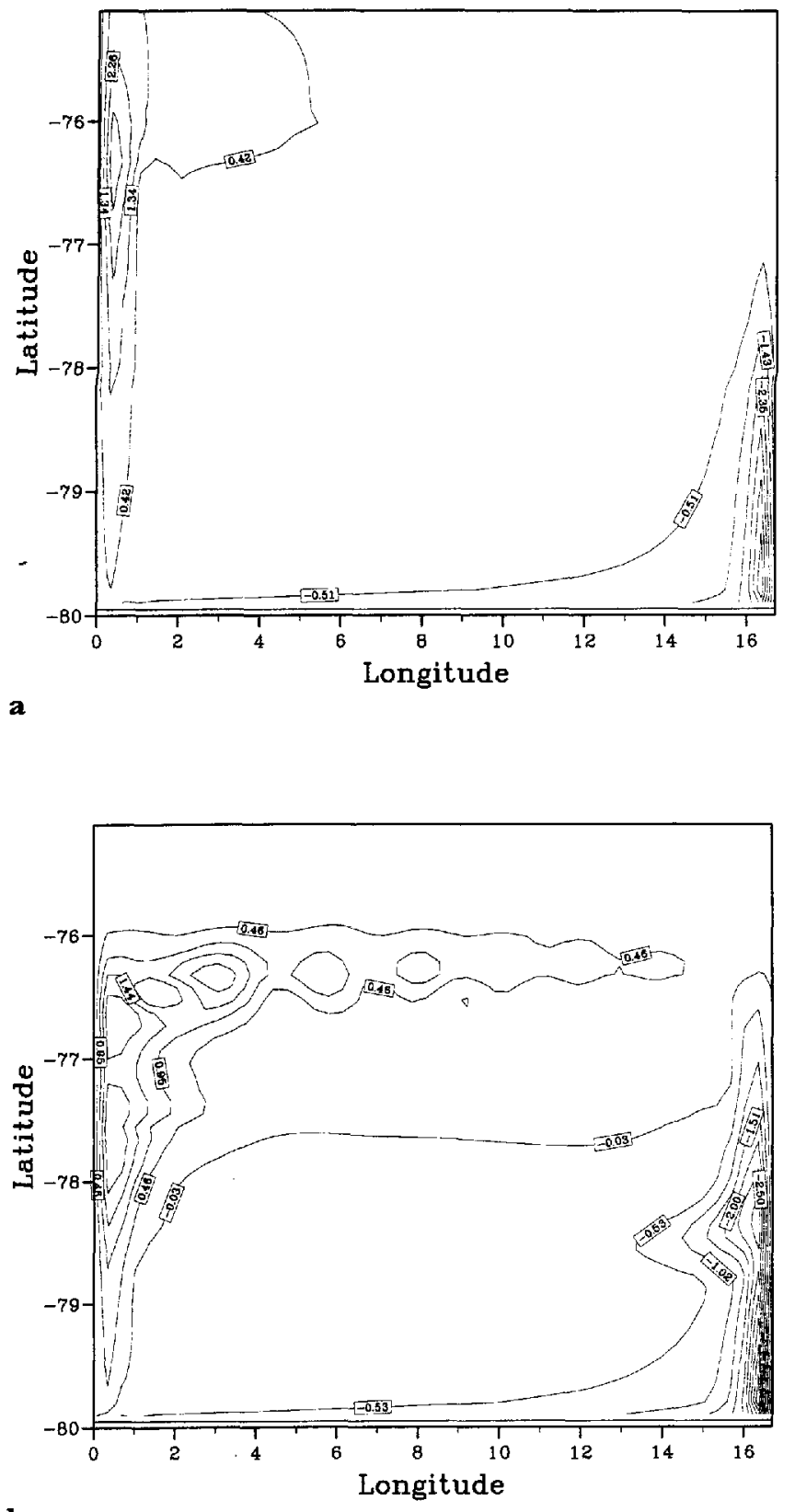

b

Fig. 6. Basal melting rates derived from model runs (a) $B$, and (b) $C$. Melting is quoted negative while basat accumul-ation appears positive. In general, strongest melting occurs in the southeastern corner of the model domain. The diluted plume propagates west, while melting rates decrease. When meeting the western boundary, a northward boundary current is initiated to transport the waler, now being caldest, to more shallow ice-shelf drafts. While rising at the ice-shelf base, the water becomes supercooled. Ice formation is soon initiated and results in maximum rates before the flat part of the ice shelf is reached at $76^{\circ} \mathrm{S}$.

This is also a region of very large mixed layer depths. In case B, strong currents are confined to the western boundary and this is where the largest fluxes occur in this case. The transition at $76^{\circ} \mathrm{S}$ has the same effect as in case $\mathrm{C}$.

To discuss the effect of an open boundary on the internal circulation, run B seems appropriate. Because it offers the highest water column $(1300 \mathrm{~m})$ towards the open ocean, interconnections should be most likely. The

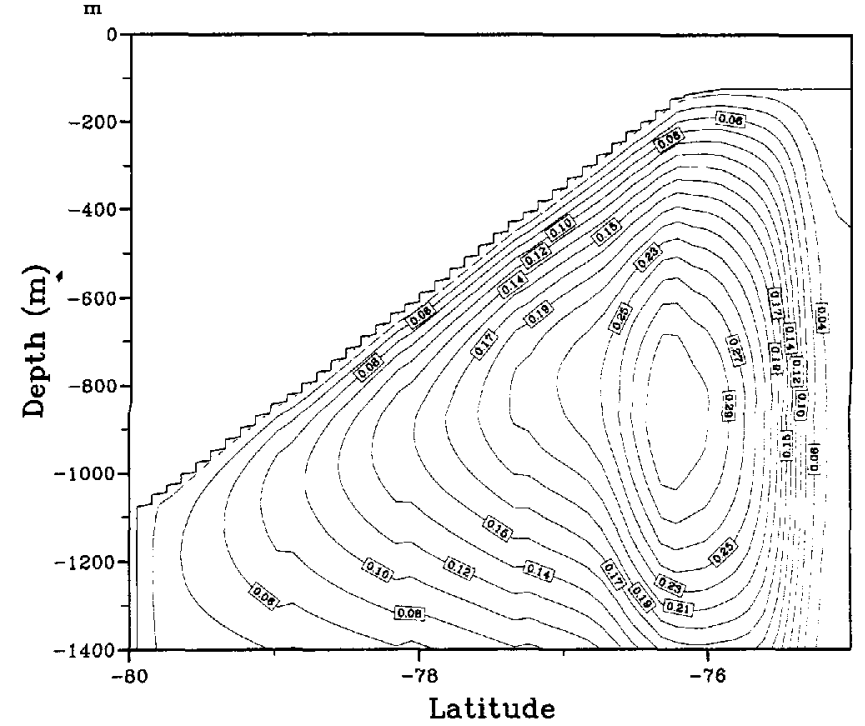

Fig. 7. Stream function of the zonally integrated mass transport for experiment $B$ with open-boundary conditions. Compare Figure $3 a$. Contour interval $0.02 \mathrm{~Sv}$.

stream function for the zonally integrated transport is shown in Figure 7, which should be compared with Figure 3a. Only a small fraction of the total transport exits from the cavity and returns as a deep inflow from the open ocean. This fraction increases slightly when the frictional fluxes of momentum across the northern boundary are increased. The deep mixing due to freezing near the ice-shelf edge presents an effective barrier for the exchange with the open occan. Sincc the inflow of water from the open ocean is so small, only very minor effects of the open-boundary condition are observed in the surface fresh-water fluxes and the vertically integrated flow.

In case $\mathrm{C}$, with a more realistic ice-shclf and bottom topography, the isolation of the ice-shelf cavity from the open ocean is even more pronounced. Figure $3 b$ has alrcady shown that in this case the circulation is mostly confined to the part with sloping ice-shclf base and bottom, and does not extend close to the northern

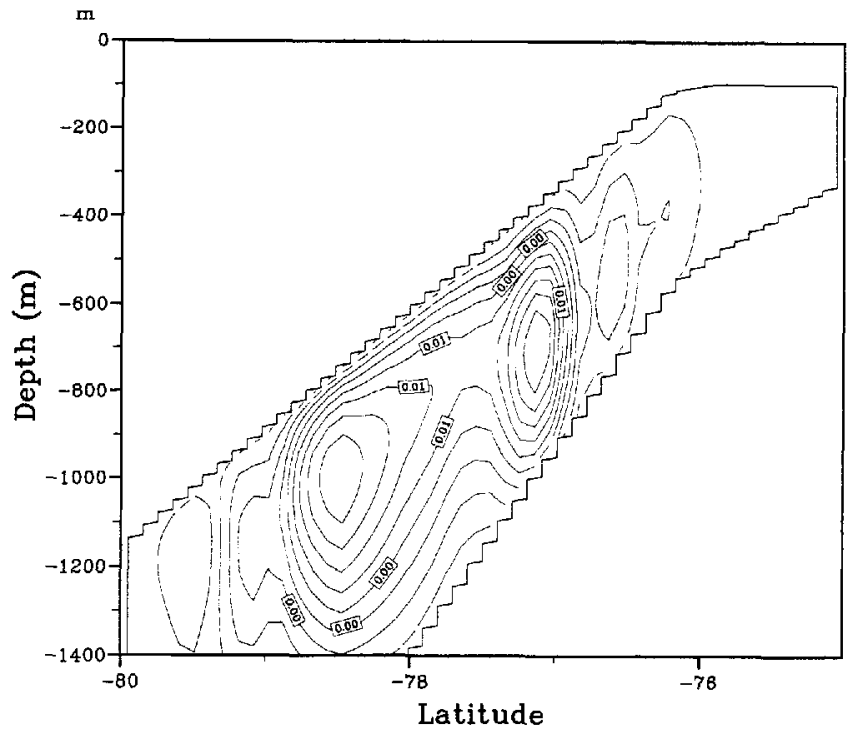

Fig. 8. Difference between the zonally integrated mass transports of experimenl $C$ with open-and closed-boundary conditions. Contour interval $0.001 S_{\mathrm{u}}$. 
boundary. As the difference in meridional transport (Fig. 8) proves, this remains true when the open-boundary condition is installed.

\section{DISGUSSION AND GONGLUSIONS}

We have prescnted first results from a model of the threedimensional flow beneath an ice shelf and the interaction belween ocean circulation and the ice shelf. We have confined the present experiments to idealized configurations, in order to simplify the interpretation of the results. In spite of the idealized configuration, we think that some preliminary conclusions can be drawn for the actual interaction of occan and ice shelf in Antarctica. Our results show that the ice-pump mechanism due to the pressure-dependence of the freezing point of sea water is ablc to cxplain phenomena of ice ocean interaction presently observed beneath the Ronne Ice Shelf. Modelled rates of basal melting close to the grounding line and of a subscquent accumulation of ice further north are consistent with observations and results of ice-shelf modelling (Determann, 1991; Jenkins and Doake, 1991). While the steepness of the ice-shell base determines the potential for melting and freezing, the water-depth distribution controls the strength and direction of ocean currents initiated by ice-ocean interactions and the sites where melting and freczing occurs.

From a comparison of model experiments with open and closed boundaries towards the open ocean, we tentatively conclude that the internal circulation of the sub-ice-shelf cavity is almost unaffected by the hydrography outside the icc-shclf front. A scenario allowing relatively warm Circumpolar Deep Water (CDW) to flush the sub-ice-shelf cavity, causing dramatic basal melting and favoring ice-shelf disintegration, is not supported by the present results. Instead, we assume that the ice-shelf watcr observed off scveral ice shelves in Antarctica originates from the near-frontal zone that is accessible to tidal currents.

Much further modelling and observational work is needed to confirm these findings. Currently, we are in the process of exploring carcfully the full sensitivity of the model to open-boundary conditions. Also, experiments, including an open ocean north of the ice-shelf front are under way. We plan to employ our circulation model for a more realistic bottom and ice-shelf topography.

\section{ACKNOWLEDGEMENT}

This is contribution No. 688 of the Alfred-WegenerInstitut für Polar- und Mccresforschung.

\section{REFERENCES}

Berendt, J. C. 1970. The structure of the Filchner Ice Shelf and its relation to bottom melting. International Association of Scientific Hidrology 86 (Symposium at Hanover, 1968-ISAGE), 488196.

Bryan, K. 1969. A numerical method for the study of the circulation of the world occan. 7. Comput. Phys, 4, 347-376.

Cox, M. D. 1984. A primitive equation, 3-dimensional model of the ocean. GFDI, Ocean Group Tech. Rep. 1
Determann, J. 1991. Numerical modelling of ice-shelf dynamics. Antart. Sci., 3 2), 187-195.

Determann, J., K. Grosfeld and B. Ritter. 1990. Melting rates at the bottom of Filchner-Ronnc Icc Shclf, Antarctica, from short-term mass-balance studies. Polarforschung, 60(1), 25-32.

Doake, C.S.M. 1976. Thermodynamics of the interaction between ice shelves and the sea. Polar Rec, 18(112),37-41.

Drrwry, D.J., ed. 1983. Antartica: glaciological and geoplysical fotio. Cambridge, University of Cambridge. Scott Polar Research Institute.

Engelhardt, II. and J. Determann. 1987. Borchole evidence for a thick layer of basal ice in the central Ronne Ice Shelf. Nature, 327 6120). 318319.

Fahrbach, E. 1993. Zirkulation und Wassermasscnbildung im Weddelmecr. Die Geowissenschajten, 11 ( 7 ; , 246-253.

Fuldvik, A., 'T. Gammelsrod and T. Torresen, 1985. Circulation and water masses on the southern Weddell Sea shelf. In.Jacobs, S.S., ed. Oceanalogy of the Antartic continental shelf. Washington, DC, Amcrican Gcophysical Union, 5-20. (Antarctic Research Serics, 43.)

Gerdes, R. 1993. A primitive equation ocean circulation model using a general vertical coordinate transformation. Part 1 : description and testing of the model. $\mathbf{J}$. Genphys. Res, $\mathbf{9 8}(\mathrm{C} 8), 14,683-14,701$.

Hellmer, H. H. and D.J. Olbers. 1989. A two-dimensional model for the thermohaline circulation under an ice shelf. Antart. Sci., 1 (4), 325-336.

Hellmer, H.H. and D. J. Olbers. 1991. On the thermohaline circulation beneath the Filchner-Ronne Ice Shelves. Antarct. Sai. 3(4), 433-442.

Jacols, S.S., H. H. Hellmer, C.S. M. Doake, A. Jenkins and R. M. Frolich. 1992. Melting of ice shelves and the mass balance of Antarcica. J. Glaciol, $\mathbf{3 8}(130)$, 375-387.

Jenkins, A. 1991. A une-dimensional model of ice shelf-ocean interaction. 7. Geophys. Res., 96(C11), 20,671--20,677.

Jenkins, $\Lambda$. and C.S. M. Doake. [991. Ice-ocean interaction on Ronne Ice Shelf, Antarctica. 7. Geophs. Res, 96(C1), 791-813.

Kohnen, H. 1982. Glaciological investigation in the frontal zone of the Filchner and Ronne Ice Shclves. Ann. Glaciol., 3, 160165

Lewis, E. L. and R.G. Perkin. 1986. Ice pumps and their rates. 7. Geophys. Res., 91:C10), 11,756-11,762.

MacAyeal, D. R. 1984. Thermohaline circulation below the Ross Icc Shelf: a consequence of tidally induced vertical mixing and basal melting. 7. Geophys. Res., 89(C) , 597-606.

Mactyeal, D. R. 1985. Tidal rectification below the Ross Ice Shelf, Antarctica. In Jacobs, S.S., ed. Ockanology of the Antarctic continental shelf. Washington, DC, American Geophysical Union, 109-132. Antarctic Research Series, 43.

Mellor, G. L. 1991. An equation of state for numerical models of oceans and estuaries. 7. Atmos. Ocean Tech., 8, 609-61l.

Mercer, J.H. 1978. West Antarctic ice sheet and $\mathrm{CO}_{2}$ greenhouse eflect: a threat of disaster. Nature, 271 5643$), 32 ! 325$.

Millero, F.J. 1978. Freczing point of sea water. Wighth Report of the Joint Pancl of Oceanographic Tables and Standards. Appendix 6 . UTESCO Tech. Pap. Mar. Sci., 28, 29-31.

Morgan, V. I. 1972. Oxygen isotope evidence for bottom freezing on the Amery Ice Shclf. Nature, 238(5364), 393-394.

Vicholls, K.W., K. Makinson and A.V. Robinson. 1991. Ocean circulation beneath the Ronne Ice Shelf. Nature, 354(6350), 221-223.

Oerter, H. and 6 others. 1992. Evidence for basal marine ice in the Filchner-Ronne lcc Shelf. Nature, 358 6385), 399-401.

Robin, G. do (2. 1979. Formation, flow, and disintegration of ice shelves. f. Glaciol., 24(90), 259-271.

Scheduikat, M. and D.J. Olbers. 1990. A one-dimensional mixed layer model beneath the Ross Ice Shell with tidally induced vertical mixing. Antarct. Sci. 2,1), 2942.

Stevens, D.P. 1991. The open boundary condition in the United Kingdom Fine-Resolution Antarctic Modcl. 7. Phys. Ocean., 21 $1494-1499$.

Thyssen, F. 1988. Special aspects of the central part of Filchner-Ronne Ice Shelf, Antarctica. Am. Glaciol., 11, 173-179.

UNESCO. 1981. Tenth report of the Joint Panel on Occanographic Tables and Standards. UNESCO Tech. Pap. Mar. Sci. 36. Paris, UNESCO.

Zotikov, I. A., V. S. Zagorodnov and J. V. Raikovski. 1980. Core drilling through the Ross Ice Shelf (Antarctica) confirmed basal freezing. Science, 207(4438), 1463-146.5.

The accuracy of references in the lext and in this list is the responsibility of the authors, to whom queries should be addressed. 